\title{
Speculation and the Small Investor
}

\author{
By Theo. H. Price \\ Fditor of Commerce and Finance
}

\section{Chance a Factor in Life}

WROM the cradle to the grave life is a speculation. It has been said that "We are all under sentence of death with an indefinite reprieve," but most of us, nevertheless, calculate upon at least an average life and make our plans accordingly. Facing, as we do from hour to hour, the chances of illness, accident or financial disaster, it is not surprising that we should become more or less callous to the hazards of existence and be willing to increase them by putting our money, when we have it, into schemes or investments that promise or are described as promising large returns.

It is the essential uncertainty of life coupled with the hope that each individual entertains that he may be more lucky than his fellows that is at the bottom of the speculative instinct that most men and women evince. This instinct is a sound one, for without it progress would be impossible.

We have the spirit of adventure to thank for nearly all the great discoveries that have advanced mankind. It has been very truthfully said that "if our alphabet were ideographic instead of phonetic, the words conservative and unprogressive would look very much alike" and the speculative instinct is not to be discouraged, for through its exercise Columbus discovered America and the political and scientific pioneers of all generations have opened up opportunities by which humanity has profited.'

\section{Pitfalis of Speculation}

In thus acclaiming speculation it is, however, important to carefully differentiate it from gambling. Speculation has been defined as hazard plus intelligence, gambling as hazard without intelligence, and if we bear these contrasting definitions in mind it will not be difficult for us to avoid the pitfalls that the unscrupulous provide for those who are willing to risk their money thoughtlessly.

In an effort to protect the careless or gullible members of society against themselves many of the states have enacted what are called Blue Sky Laws designed to make fraudulent promotion, over-capitalization and stock swindles impossible, but there are no laws that can give a fool immunity from the consequence of his folly, and it is questionable whether the Blue Sky Laws haven't done more harm than good in that they lead many to believe that the securities that are issued in accordance with their provisions may be bought as safe investments without further investigation.

It is, in fact, extremely doubtful whether the judgment of men can be educated or clarified by legislation which seeks to make the exercise of a discriminating and studious intelligence unnecessary, and since chance is a factor in the problem of life that cannot be eliminated, a study of the law of chance is necessary in order to deal with it intelligently. 


\section{The Law of Chance}

The great astronomer, Richard Anthony Proctor, was the first authority of note to develop the law of chance. By a series of experiments extending over a number of years he discovered and proved that where the chances were theoretically equal, it was necessary that they should be taken an almost infinite number of times in order that the results might equally counterbalance each other. Thus, he asserts, it is not certain that a well balanced coin thrown into the air even a million times will come down heads up 500,000 times and tails up 500,000 times at the end of the experiment, and the first postulate of the law of chance that should be taken into consideration is the factor of luck. We must make allowance for it in all our calculations and endeavor, in so far as it is humanly possible, to put ourselves beyond its operation. For this reason, no one should embark in any speculation, however promising, unless his knowledge of the business involved and the conditions surrounding it are sufficiently intimate and personal to enable him to feel sure that the probabilities at least favor the expectation of a profitable result.

\section{Chance Investments}

Since no one can be thoroughly informed with regard to more than one or two of life's more important financial, industrial, commercial or agricultural activities, it is a corollary of the foregoing statement that it is exceedingly unwise and hazardous for anyone to put his money into a business with which he is unfamiliar unless he makes the investment upon the advice of a trustworthy person in whose knowledge of the proposed investment he has profound confidence.
It is, for instance, foolish for a farmer to invest his hard earned savings in land that he has never seen and concerning whose agricultural possibilities or market value he has no first hand knowledge. It is equally foolish for any one else, no matter how he may have made his money, to invest it in any security of whose value he cannot convince himself by personal examination or in regard to which he is unable to obtain trustworthy information from a person in whose knowledge and good faith he has complete confidence.

As a generalization, therefore, it may be said that it will be wise to make it a rule not to invest any money in things concerning which we are unable to inform ourselves by personal examination, unless we base our action upon the advice of those who are specialists in the business concerned and of whose integrity we are entirely confident. In the field of corporate investments, meaning thereby the stocks and bonds of corporations, there are throughout the United States a number of high class and responsible concerns, firms or companies whose business it is to select sound enterprises in which the money of their clients may be invested. To the consideration of the problems involved they bring years of experience and training. They are thoroughly alive to the fact that if they make mistakes they will lose the prestige and confidence that they enjoy in the financial world, and while they err occasionally their judgment is, as a rule, sound. It is, therefore, safe to say that no one having money to invest should buy the securities of any corporation unless they are recommended or endorsed by some responsible investment concern.

The fly-by-night-salesman who comes into your town with a fairy 
story in regard to the distant oil well or mine into which he asks you to put your money should be summarily dismissed with the suggestion that he submit his proposals to the nearest successful banker and that you will consider them only after that banker has approved of them. The land agent who seeks to sell you property in the Everglades of Florida or the Great American Desert upon the theory that it can be reclaimed and made to blossom like the rose by the expenditure of a little money should be similarly treated. The promoter of a company that controls a patent for a machine that will do the work of one thousand men should be required to furnish indubitable proof of the machine's efficiency and its successful commercialization before you allow him to persuade you to put your hard earned savings into the corporation that has been organized for its development.

If you are, however, disposed to take long chances and are convinced of the good faith and honesty of those who are inviting you to make the hazard you should then feel sure that the odds in your favor are sufficiently high enough. For those who have money and are willing to risk a small portion of it in something that promises very large profits but involves, nevertheless, great hazard, an intelligent investment made upon a basis that promises, say, a profit of $\$ 100$ for every dollar invested is not perhaps unwise, but in making hazardous investments of this sort care should be taken to apply the principle of average as in the case of insurance, and a sufficient number of such investments should be made in different enterprises to allow for an unfavorable result in the case of most of them.

There are some investors who apply this law of average scientifically. They put a small sum into each new enterprise that is brought to their attention under respectable auspices upon the theory that although only one out of each ten may turn out profitably their gain will be sufficient to more than offset the losses that they will sustain in the case of the other nine. It is, however, hardly practicable for the average investor who has but an occasional opportunity to put his money into these extra hazardous though promising enterprises to adopt such a policy, and even if he did, it is questionable whether he would have the courage to pursue it in the case of the tenth investment if his nine previous ventures had been unsuccessful. The only wise course for him to pursue is, therefore, to refuse to embark upon any speculation concerning whose hazards he is not thoroughly informed, either by personal observation and experience or the testimony of those in whom he has confidence.

If he follows this rule he may possibly miss an occasional but very remote opportunity for making a large profit but he will, on the other hand, be reasonably sure to avoid the loss of his capital and will be certain to enjoy the complacency of mind which comes to those who insist upon "safety first" in the use of their money. 